\title{
THE LEVEL OF KNOWLEDGE AND ATTITUDES OF PHARMACY STUDENTS TOWARDS CORTIOSTEROIDS USES
}

\author{
Tri Budi Julianti ${ }^{*}$, Deasy Nur Chairin Hanifa ${ }^{1}$ \\ ${ }^{1}$ Department of Pharmacy, Faculty of Health and Pharmacy, Universitas Muhammadiyah \\ Kalimantan Timur, Indonesia. \\ *E-mail : tbj470@umkt.ac.id
}

\begin{abstract}
Corticosteroids are hormones that naturally produced by the human body through the adrenal gland. Cortisone hormones play a role in regulating blood sugar, protein, fat, the body's defense system and bone formation. Corticosteroid drugs are commonly used for anti-inflammatory, pruritic, dermatological, rheumatologic, pulmonary, hematological, ophthalmological, immunological, and gastrointestinal, called glucocorticoids. Long-term therapy with corticosteroids can cause severe side effects if given in high doses. The aim of this study was identification of the level of knowledge and attitude in corticosteroid use, especially in pharmacy students. This type of research was cross-sectional which aims to see the relationship between the dependent variable and the independent variable in Samarinda. This research was conducted in 2019 by conducting a questionnaire survey test using Google Form. Data analysis in the form of bivariate analysis using the Mann-Whitney test with SPSS Statistic 23 software program. Respondents who participated in this research amounted to 118 people with ages ranging from 17 to 25 years. In this research shows that pharmacy students have a fairly good knowledge of corticosteroids with the majority of the percentage of correct answers $\geq 72 \%$. The results of the analysis obtained $p$ value 0.008 $(\mathrm{p}<0.005)$ and obtained $\mathrm{r}$ value 2.7. There is a significant influence between knowledge of corticosteroids on their attitude using corticosteroids and showing good knowledge has the potential of 2.7 times to have a good attitude.
\end{abstract}

Keywords: Attitude, Corticosteroid, Knowledge, Pharmacy Student

\section{INTRODUCTION}

Corticosteroids are a class of steroid hormones released by the adrenal cortex, which includes glucocorticoids and mineralocorticoids. Cortisone hormone is useful for inhibiting the inflammatory response, encouraging gluconeogenesis, sodium retention, and releasing potassium from the body (mineralocorticoids). Corticosteroid synthesis was created to have the same mechanism of action as natural corticosteroids ${ }^{1,2}$. Corticosteroids are not only used in humans but are widely used in veterinary therapy in the form of exogenous corticosteroids. So the use of corticosteroid synthesis is widely made in helping most medical conditions. Corticosteroid drugs are commonly uses for anti-inflammatory, pruritus, dermatologic, rheumatic, pulmonary, hematological, ophthalmological, immunological, and gastrointestinal (GI) diseases so that the term corticosteroid is assumed to be glucocorticoid. Corticosteroids (CS) have long been known as the most powerful of all known anti-inflammatory agents ${ }^{3,4,12}$. Corticosteroid therapy in the long term can cause severe side effects if given in high doses, such as osteoporosis, fractures, cardiovascular disease, hypertension, diabetes alkalosis, hypokalemia, hyperglycemia, dyslipidemia, decreased immunity, gastritis, growth disorders, cataracts, moon face, 
hypertension neuropsychiatric disorders, immunosuppression, and obesity. But so far many of the risks or side effects that exist cannot be prevented ${ }^{3,5}$.

Before we consume the drug, needed knowledge related to the indications and how to use the drug to be consumed. It is hoped that the right knowledge will show the right attitude in the use of drugs. However, in the use of corticosteroids that are so widespread, there are many discrepancies in use with the indication, dosage, and duration of administration. Therefore, a deep and correct understanding of the use of corticosteroids is needed both pharmacokinetic, pharmacodynamic, physiological in the body and the side effects of the use of these drugs. Prior study show that serious side effect of corticosteroids affect almost $50 \%$ of patient with chronic disease conditions due to lack of patient compliance with corticosteroids treatment ${ }^{12}$. Based on this description, this study wants to see the level of knowledge and attitudes in the use of corticosteroids, especially in pharmacy students.

\section{Material}

\section{MATERIAL AND METHOD}

This is a cross-sectional research that aims to see the relationship between the dependent variable and the independent variable. This research was conducted in 2019 by conducting a questionnaire survey test using Google Form. The sample in this study was Pharmacy students in Samarinda, with inclusion criteria, namely over the age of 17 years, live in Samarinda, approving informed consent, and filling in the google form completely. Study samples were asked to choose answers on the questionnaire.

\section{General procedure}

This study uses a Google Form questionnaire survey test. The questionnaire used had one section related to basic demographics (age, sex, and type of corticosteroid that had been used), then the knowledge section about corticosteroids which included questions about indications, side effects, rules of use, and how to obtain corticosteroids. The next section is about experience in consuming oral corticosteroids. All answers are accumulated based on total scores and then data analysis is performed.

\section{Analytical Discussion}

Data analysis in the form of bivariate analysis using the Mann-Whitney test with SPSS Statistic 23 software program with p-value 0.05 . Participation in this study is voluntary, and all data obtained is kept confidential.

\section{RESULTS AND DISCUSSION}

Corticosteroids are drugs that are known to have many benefits and are commonly used for anti-inflammatory, pruritic, dermatological, rheumatological, pulmonary, hematological, ophthalmological, immunological, and gastrointestinal (GI) diseases ${ }^{3}$. The many benefits of using corticosteroids require in-depth knowledge before using them, to avoid mismatching indications, dosages, and duration of administration. It's known that there is the misuse of corticosteroids, one of which is topical corticosteroids which cause skin damage ${ }^{6}$. The problem of corticosteroid abuse had become a global problem ${ }^{7}$. The absence of regulations governing the purchase of corticosteroids must be prescribed by a doctor, many people who get it incorrectly and use it not according to the indications. 
This research try to determine the level of knowledge and attitudes of pharmacy students on the use of corticosteroids. Pharmacy students as pharmacists who had a role in preventing abuse were expected to have the right knowledge and attitude in consuming a drug. In previous studies involving pharmacy students, it was known that self-medication or self-medication and giving advice regarding treatment to others was very prevalent among pharmacy students ${ }^{8}$. Obtained data, there were $38.2 \%$ of respondents gave advice on corticosteroid treatment. It shows the important role of pharmacists and students as prospective pharmacists in preventing the abuse of corticosteroids and the use of corticosteroids must be based on a prescription from a doctor?.

The total number of respondents who participated in the research was 118 people with age ranges ranging from 17 to 25 years. There were 93 female respondents and 25 male respondents. Our results show that corticosteroid drugs commonly used were Dexamethason, Methylprednisolone, Prednisone, and Betamethasone. The results of the research on the description of the respondent's knowledge related to corticosteroids could be seen in table 1 and a description of respondent's attitudes related to corticosteroid use could be seen in table 2 .

Table 1. Overview of Respondents Knowledge related to Corticosteroids

\begin{tabular}{clcc} 
Number & \multicolumn{1}{c}{ Question } & $\begin{array}{c}\text { Number of Answer } \\
\text { Correct }(\mathbf{n = 1 1 8})\end{array}$ & $\begin{array}{c}\text { Percentage } \\
(\mathbf{\%})\end{array}$ \\
\hline 1 & General indication for corticosteroids & 101 & 85,6 \\
2 & Corticosteroid side effects & 53 & 44,9 \\
3 & Time to start consuming corticosteroids & 101 & 85,6 \\
4 & Discontinuation of corticosteroid use & 102 & 86,4 \\
5 & How to obtain corticosteroids & 105 & 89 \\
6 & Get corticosteroids without a doctor's & 54 & 45,8 \\
& prescription & 114 & 96,6 \\
7 & Indications corticosteroids for inflammation & 85 & 72 \\
8 & The use of corticosteroids for various & 99 & 83,9 \\
9 & diseases & & 74,6 \\
10 & Corticosteroid Prescribing & 88 & 99,2 \\
11 & Long-term corticosteroid consumption & 117 & 3,4 \\
\hline
\end{tabular}


Table 2. Overview of Respondent's Attitudes Regarding Corticosteroid Use

\begin{tabular}{|c|c|c|c|c|c|c|c|c|}
\hline \multirow[t]{2}{*}{ Number } & \multirow[t]{2}{*}{ Statement } & \multicolumn{5}{|c|}{ Answer choice } & \multirow{2}{*}{$\begin{array}{c}\text { Average } \\
\text { Index } \\
(\%)\end{array}$} & \multirow[t]{2}{*}{ Category } \\
\hline & & $\begin{array}{c}\text { Strongly } \\
\text { disagree } \\
(\%)\end{array}$ & $\begin{array}{c}\text { Disagree } \\
(\%)\end{array}$ & Neutral & $\begin{array}{c}\text { Agree } \\
(\%)\end{array}$ & $\begin{array}{c}\text { Strongly } \\
\text { Agree } \\
(\%)\end{array}$ & & \\
\hline 1 & $\begin{array}{l}\text { I ever used } \\
\text { corticosteroids } \\
\text { to treat my } \\
\text { illness without } \\
\text { a doctor's } \\
\text { prescription. }\end{array}$ & $\begin{array}{c}42 \\
(35,59)\end{array}$ & $\begin{array}{c}32 \\
(27,12)\end{array}$ & 0 & $\begin{array}{c}39 \\
(33,05)\end{array}$ & $5(4,24)$ & $48,64 \%$ & Enough \\
\hline 2 & $\begin{array}{l}\text { I used } \\
\text { corticosteroids } \\
\text { prescribed by } \\
\text { the doctor only } \\
\text { when } \\
\text { symptoms } \\
\text { recur. }\end{array}$ & $\begin{array}{c}23 \\
(19,49)\end{array}$ & $\begin{array}{c}27 \\
(22,88)\end{array}$ & 0 & $\begin{array}{c}50 \\
(42,37)\end{array}$ & $\begin{array}{c}18 \\
(15,25)\end{array}$ & $62,2 \%$ & Good \\
\hline 3 & $\begin{array}{l}\text { I used } \\
\text { corticosteroids } \\
\text { to treat various } \\
\text { diseases. }\end{array}$ & $\begin{array}{c}61 \\
(51,7)\end{array}$ & $\begin{array}{c}35 \\
(29,66)\end{array}$ & 0 & $\begin{array}{c}19 \\
(16,1)\end{array}$ & $3(2,54)$ & $82,54 \%$ & $\begin{array}{l}\text { Very } \\
\text { Good }\end{array}$ \\
\hline 4 & $\begin{array}{l}\text { I stopped using } \\
\text { corticosteroids } \\
\text { when my } \\
\text { illnesses were } \\
\text { cured. }\end{array}$ & $\begin{array}{c}10 \\
(8,48)\end{array}$ & $8(6,78)$ & 0 & $\begin{array}{c}51 \\
(43,22)\end{array}$ & $\begin{array}{c}49 \\
(41,53)\end{array}$ & $80,51 \%$ & $\begin{array}{l}\text { Very } \\
\text { Good }\end{array}$ \\
\hline 5 & $\begin{array}{l}\text { If } \\
\text { corticosteroids } \\
\text { remain, I } \\
\text { would save } \\
\text { them for later } \\
\text { use. }\end{array}$ & $\begin{array}{c}17 \\
(14,41)\end{array}$ & $\begin{array}{c}25 \\
(21,19)\end{array}$ & 0 & $\begin{array}{c}63 \\
(53,39)\end{array}$ & $\begin{array}{c}13 \\
(11,02)\end{array}$ & $65,08 \%$ & Good \\
\hline 6 & $\begin{array}{l}\text { I had special } \\
\text { storage for } \\
\text { save } \\
\text { corticosteroids. }\end{array}$ & $\begin{array}{c}15 \\
(12,71)\end{array}$ & $\begin{array}{c}18 \\
(15,25)\end{array}$ & 0 & $\begin{array}{c}65 \\
(55,09)\end{array}$ & $\begin{array}{c}20 \\
(16,95)\end{array}$ & $69,66 \%$ & Good \\
\hline
\end{tabular}

This research showed that pharmacy students have a good knowledge related to corticosteroids with the majority of the percentage of correct answers $\geq 72 \%$. But knowledge on the side effects of using corticosteroids and purchasing corticosteroids without a doctor's prescription was lack. Side effects of a drug could occur directly and indirectly (long term), so the needed for knowledge related to side effects to avoid undesirable effects. It's important for pharmacy students who would manage corticosteroid prescriptions in the future. There was needed for training programs that are designed to increase the knowledge of pharmacy students 
regarding the understanding of the drug. The importance of having a correct understanding before they give advice to others. A study shows that misleading information provided by pharmacists leads to a large impact in the form of perceptions of corticosteroid use in the general population ${ }^{9}$. Knowledge of ethical and rational corticosteroid use must be disseminated ${ }^{10}$.

This research showed that the habits or attitudes of pharmacy students in the use of corticosteroids were appropriate with the average index showing the majority of good and excellent categories, which include the purpose of use (indications), rules of use, storage, and how to obtain cortic osteroids. In this research was found that there were still habits or attitudes of pharmacy students in storing corticosteroids that were still left for later use. It was necessary to educate about the use of corticosteroids with the aim of using them in accordance with the direction of health workers who were competent in their fields. Competent health workers in this regard, namely doctors and pharmacists ${ }^{11}$. In addition, the use of an individual drug-influenced by several factors, including age, clinical condition, the severity of the condition, accurate diagnosis, optimal dose choice, frequency of administration, duration of therapy, and side effects.

Our results analyzed using the Mann-Whitney test showing a significant influence between one's knowledge of corticosteroids on their attitude to using corticosteroids with a pvalue of $0.008(\mathrm{p}<0.005)$. In this research the value of $\mathrm{r}$-value 2.7 was obtained, this shows that someone with good knowledge has 2.7 times the potential to have a good attitude as well. Therefore, the use of corticosteroid in clinical practice requires educating users about the safety, potency, and rules of proper use in various dosage forms. Appropriate information on the use of corticosteroids would achieve an effective therapeutic approach ${ }^{12}$.

\section{CONCLUSION}

Taken all together we concluded that there is a significant influence between knowledge about corticosteroids to their attitudes using corticosteroids with a p-value of 0.008 ( $p<0.005$ ) and an r-value of 2.7 is obtained, this shows that someone with good knowledge has the potential of 2.7 times to have a good attitude too. 


\section{REFERENCES}

1. Ramamoorthy, S., dan John A.C., Rheum Dis Clin North Am. 2016 February ; 42(1): 1531.

2. $\quad$ Trikoso N. 2016;(April).

3. Yasir M, Sonthalia S. Treasure Island (FL): StatPearls Publishing; 2019 Jan. Available from: https://www.ncbi.nlm.nih.gov/books/NBK531462/

4. Mark G. Papich DVM, MS, DACVCP. Saunders Handbook of Veterinary Drugs (Fourth Edition) [Internet]. 2016, Pages 806-808. Available from:: https://www.sciencedirect.com/science/article/pii/B9780323244855005672

5. Liu, D., Ahmet, A., Ward L, Krishnamoorthy, P., Mandelcorn ED, Leigh, R., Brown, J.P., Cohen, A. D, Kim H. Allergy, Asthma Clin Immunol [Internet]. 2013;9(1):1-25.

6. $\quad$ Dey VK. Indian Dermatol Online J 2014;5:436-40.

7. Al Hawsawi K, Alaauldeen S, Albarnawi N, Mashrai H, Alosaimi R, Alsufyani H, et al.. Int J Adv Res 2017;5:297-307.

8. Alkhatatbeh MJ, Alefan Q, Alqudah MA. Int J Clin Pharmacol Ther 2016;54:390-8.

9. Smith, S.D.; Hong, E.; Fearns, S.; Blaszczynski, A.; Fischer, G. Australas. J. Dermatol. 2010, 51, 168-174.

10. Ashique KT, Kaliyadan F, Mohan S, Vijayan S, Chandrasekhar D. Indian Dermatol Online J 2018;9:432-4.

11. Republik Indonesia. 2009. Undang-undang Nomor 36 Tahun 2009 Tentang Kesehatan. Lembaran Negara Republik Indonesia Tahun 2009 Nomor 144. Sekretariat Negara RI. Jakarta.

12. Mahdy A, Hussain N, Al Khalidi D, Said ASA. Natl J Physiol Pharm Pharmacol 2017;7(6):562-568. 